\title{
Ability of Al-acclimatized Immobilized Nostoc muscorum to Combat Abiotic Stress and its Potential as a Biofertilizer
}

\author{
Adeeba Shamim² (D), Sadaf Mahfooz ${ }^{2}$ (D) Arbab Hussain² ${ }^{(D)}$ and \\ Alvina Farooqui ${ }^{1 *}$ (iD \\ ${ }^{1}$ Department of Bioengineering, Faculty of Engineering, Integral University, Lucknow - 226 026, India. \\ ${ }^{2}$ Department of Biosciences, Faculty of Applied Sciences, Integral University, Lucknow - 226 026, India.
}

\begin{abstract}
In the present study, an engineered cyanobacterial biofertilizer (immobilized Al- acclimated cyanobacterial cells) which could be further used as inoculum to affect the overall productivity of containerized rice plants has been proposed. The cyanobacterium Nostoc muscorum (N. muscorum) was well acclimatized to Al metal by initially subjecting the cells to very low dose $(0.1 \mu \mathrm{M})$ of $\mathrm{Al}$ and subsequent transfer every 15 days to the higher concentrations $(1,10,20,30,40$ and $60 \mu \mathrm{M})$ of $\mathrm{Al}$ with regular growth study at each step of cells transfer to the higher concentration and immobilized in calcium alginate beads and were examined for their growth in terms of content of chlorophyll $a$, heterocyst frequency and ammonia excretion. Growth was more pronounced in Al- acclimatized immobilized state than under free state. Heterocyst frequency and ammonia excretion were considerably higher under immobilized state than under free-living conditions. Results also showed the ameliorative role of Al-acclimatization in $\mathbf{N}$. muscorum exposed to UV stress. Air dried Al-acclimatized immobilized cells stored under light, temperature, air and dust retained the ability to regenerate the viable colonies for upto months. From the experiments performed, it is witnessed that calcium alginate does not cause any opposing effect on regeneration potential and $\mathrm{N}_{2}$ - fixing capability of $\boldsymbol{N}$. muscorum and the airdried beads are appropriate to store and easy to transport. Thus the present study will provide stress tolerant biofertilizer with improved storage capability and portability enabling more sustainable and efficient production in agriculture.
\end{abstract}

Keywords: Cyanobacteria, Al- acclimatization, Immobilization, Abiotic stresses, Biofertilizer

*Correspondence: farooqui.alvina@gmail.com; +915222890730

(Received: February 11, 2020; accepted: March 20, 2020)

Citation: Shamim A, Mahfooz S, Hussain A, Farooqui A. Ability of Al-acclimatized Immobilized Nostoc muscorum to Combat Abiotic Stress and its Potential as a Biofertilizer. J Pure Appl Microbiol. 2020;14(2):1377-1386. doi: 10.22207/JPAM.14.2.35

(C) The Author(s) 2020. Open Access. This article is distributed under the terms of the Creative Commons Attribution 4.0 International License which permits unrestricted use, sharing, distribution, and reproduction in any medium, provided you give appropriate credit to the original author(s) and the source, provide a link to the Creative Commons license, and indicate if changes were made. 


\section{INTRODUCTION}

Bio-fertilizers are eco-friendly and have been proved to be effective and economical substitute of chemical fertilizers with smaller input of capital and energy (Bhardwaj et al. 2014). The blue green algae (cyanobacteria) are proficient of fixing the atmospheric nitrogen and change it into an available form essential for plant growth (Song et al. 2005). Cyanobacteria are one of the key machineries of the nitrogen fixing biomass in paddy fields and due to this feature of nitrogen fixation, they contribute to increase productivity in a variety of agricultural and ecological situations (Brahmaprakash et al. 2012).

Soil acidity is a key environmental and economic concern. Crop production is restricted by acid soil on $30-40 \%$ of the world's arable land and up to $70 \%$ of the world's potentially arable land (Pinkerton and Simpson, 1986). Although the combination of mineral toxicities (aluminum and manganese) and deficiencies (phosphorus, calcium, magnesium, and molybdenum) is attributable to the poor fertility of acid soils, yet Al toxicity is the only most important factor, being a major restriction for crop production on $67 \%$ of the overall acid soil area and is a cause of environmental distress (Barcelo and Poschenrieder 2002). Therefore, this article will focus on novel strategy of constructing cyanobacterial biofertilizer to overcome Al toxicity in acid soils.

The first target site of absorbed Al may differ among plant cultivars but the significant part (30-90\%) was found in the apoplast (Rengel 1996). The rapid binding of Al to sensitive binding sites of the apoplast causes opposition for these binding sites with other ions (Horst 1995). These Al-induced alterations in cell wall can cause the inhibition of water and mineral uptake replicating drought stress. In addition, the rigid arrangement of the plasma membrane produced by Al toxicity can also disturb the uptake of water and ions (Fodor et al. 1995)

One of the potentially important mechanism of Al stress tolerance is osmotic adjustment which is mainly disturbed by dehydration stress caused by the metal. Accumulation of compatible solutes like proline under certain metal toxicity is one of the major responses of microalgae and plants, which is possibly concomitant with the defense of plant cells against oxidative damage and with signal transduction (Choudhary et al. 2007). The basis for comparing the response in plants and cyanobacteria against water-stress is 2 -fold. Besides being the possible progenitors of higher plant chloroplasts, various cyanobacteria exhibit significant tolerance to desiccation.

Although, Al is viewed as toxic element yet it has been observed to stimulate growth at low concentration or induce other desirable effects. There are reports indicating that $\mathrm{Al}$ has a beneficial effect on plant growth and this seems to be especially true for native plant species that are adapted to acid soils (Ma et al. 2001).

Acclimatization is a gradual, longterm response of an organism to changes in its environment. In general, organisms are able to adapt after small variations in their surroundings, or even resistant to and can endure dramatic changes (Foyer et al. 2009). Acclimation of cyanobacteria to metals is the result of many different physiological and biochemical mechanisms, including a series of integrated events from stress signal perception, transduction to regulation of gene expression, which lead to the adaptive changes in growth, antioxidant defenses and many other changes at the molecular level (Kozlowski and Pallardy, 2002; Zhang et al. 2004; Yin et al. 2005; Lei et al. 2006). The immobilization of biological species within inert frameworks, producing so-called hybrid materials, has promptly evolved into a highly prosperous research field owing to the vision of many scientists.

There is great range within these hybrid materials; nevertheless, in our study we shall focus solely on the encapsulation of photosynthetically active cyanobacterial cells. Even though cyanobacteria have the capacity to fix atmospheric nitrogen but it has been witnessed that immobilized cyanobacteria have greater potential to fix nitrogen than its counterparts, i.e., free cells (Gendel and Nohr 1989). Immobilization process unlocks the possibility of appropriate storage and transportation of required cyanobacterial strains for using them as inoculum in crop field and in poor quality soil to escalate the fixed nitrogen content. Very limited studies have been reported on using immobilized cyanobacteria for enhancing nitrogen fixation (Syiem and Bhattacharjee 2010). Our study will be helpful to fully understand the 
diverse bioregulatory role of immobilization on nitrogen fixation in cyanobacteria.

The present work was thereby designed keeping in view that Al acclimatization of cyanobacterial cells will make them resistant not only to Al stress but also to other abiotic stresses mediated by over expression of proline and subsequent immobilization of Al acclimatized cells will enhance their efficacy as biofertilizer as a result of enhanced activity of nitrogen fixing apparatus. Thus, this study is an attempt to explore the possibility of using the techniques of acclimatization and immobilization for improved tolerance to abiotic stresses, enhanced storage and nitrogen fixing capability without affecting their desired characteristics over a long period of time.

\section{MATERIAL AND METHODS}

Experimental organisms and growth conditions Cyanobacteria Nostoc muscorum (N. muscorum) was obtained from Department of Botany, University of Allahabad and Department of Biological Sciences, Allahabad Agricultural Institute, Deemed University, Allahabad, respectively. Axenic culture of test organisms was maintained in the culture room at $27 \pm 2^{\circ} \mathrm{C}$. For regular experiments, cultures were grown in BG 11 medium (pH 7.0) (Huges 1958) under photosynthetic photon flux density (PPFD) of $75 \mu \mathrm{molm}^{-2} \mathrm{~s}^{-1}$ and $14 \mathrm{~h}$ photo period. The cultures were manually shaken two to four times daily.

Rice (Oryza sativa) variety Saryu 52 was obtained from Department of Botany, NBRI, Lucknow. The seeds were surface sterilized with $1 \%$ sodium hypochlorite solution for $10 \mathrm{~min}$ and successively rinsed thoroughly with double distilled water and grown on autoclaved petri plates. These petri plates were irrigated with double distilled water from time to time.

\section{Experimental setup with rice seedlings}

The effect of selected cyanobacterium $N$. muscorum-based biofilms were investigated with rice crop in the pots. The mean temperature range was between $26-28^{\circ} \mathrm{C}$ in December of the area during the crop growth. The experimental design was arranged in pots, which included 8 treatments, including controls.

Acclimatization of $\mathbf{N}$. muscorum to Al

Briefly, the stock solution of $\mathrm{AlCl}_{3} \cdot 6 \mathrm{H}_{2} \mathrm{O}$
$(1000 \mu \mathrm{M})$ was prepared in glass-distilled water and sterilized by passing through the Millipore membrane filter $(0.22 \mu \mathrm{m})$. Cylindrospermum sp. never exposed to Al has been used and is henceforth referred to as the control strain. For the acclimatization of the $N$. muscorum, cells were initially subjected to very low dose $(0.1 \mu \mathrm{M})$ of $\mathrm{Al}$ and subsequently transferred every 15 days to the higher concentrations $(1,10,20,30,40$ and 60 $\mu \mathrm{M})$ with regular growth study at each step of cells transfer to the higher concentration. Physiological acclimation of the control strain was obtained by successive sub-cultivation at increasing doses of Al up to $60 \mu \mathrm{M}$ (hereafter referred to as the acclimatized strain) as described by Rai et al. 1991. The protein contents were measured by the Lowry et al.1951 at each successive treatment with higher dose of Al to see the proper growth of $N$. muscorum.

\section{Immobilization}

Immobilization was carried out as described by Syiem, 2005. Sodium alginate solution $1.5 \%(\mathrm{w} / \mathrm{v})$ was prepared in BG-11 medium by warming the solution in a water bath. $3 \mathrm{ml}$ of 15-day-old culture was added after the solution cooled down to room temperature. The solution was mixed thoroughly and using a syringe canula, the mixture was added dropwise into $100 \mathrm{ml}$ of $1 \% \mathrm{CaCl}_{2}$ solution in a laminar flow cabinet. Calcium alginate beads ( $2 \mathrm{~mm}$ dia size) formed in the $\mathrm{CaCl}_{2}$ solution were left in the same solution for hardening at $4^{\circ} \mathrm{C}$ for $1 \mathrm{hr}$. The beads were harvested and washed with sterile distilled water and BG-11medium. These were then transferred to flasks containing BG-11medium and kept at $25 \pm 2^{\circ} \mathrm{C}$ and at a photon flux rate of $20 \mu \mathrm{mol} \mathrm{m}^{-2} \mathrm{~s}$ ${ }^{1}$ for further study.

\section{Growth measurement}

Chlorophyll a from each sample was extracted in $80 \%$ acetone and the content of the pigments was determined from absorbance at 663 nm using the method of Myers and Kratz 1955. Specific growth rate was calculated by using the equation $\mu=[\ln (\mathrm{Bf} / \mathrm{Bi})] / 10$. Where $\mathrm{Bi}$ is the initial chlorophyll a and $\mathrm{Bf}$ is the chlorophyll a at the end of 10 th day of incubation.

\section{Estimation of protein}

Protein was measured by the method developed by Lowry et al. 1951 and modified by Herbert and Phipps, 1971. 
Table 1. Specific growth rate $\left(\mu_{\max }\right)$ of free living, Al- acclimatized and Al- acclimatized immobilized N. muscorum

\begin{tabular}{lccc}
\hline Parameters & Control & Al- acclimatized & Al- acclimatized Immobilized \\
\hline $\begin{array}{l}\text { Specific growth rate } \\
\mu_{\max } \text { (day-1) }\end{array}$ & $0.13 \pm 0.2$ & $0.14 \pm 0.2$ & $0.16 \pm 0.2$ \\
\hline
\end{tabular}

The values represent Means $\pm S E(n=3)$. All the treatments are significantly different $(P<0.01)$

from control(Student's t-test). $\mu_{\max }=$ maximum specific growth rate.

\section{Measurement of malondialdehyde (MDA)}

Cells from $10 \mathrm{ml}$ of different test samples were collected by centrifugation and washed twice in $5 \mathrm{mM}$ phosphate buffer (pH 7.0). The cellular pellets were homogenized in $50 \mathrm{mM}$ phosphate buffer. The resulting homogenate was centrifuged at $8000 \mathrm{rpm}$ for $20 \mathrm{~min}$. Thiobarbituric acid reactive MDA production as a result of lipid peroxidation was measured by the method of Heath and Packer 1968.

\section{Desiccation of Immobilized Beads}

Freshly prepared immobilized Cylindrospermum sp. beads were left to air dry openly on a Petri plate inside the culture room. They were left unattended and were periodically checked for viability after being transferred to nutrient medium.

\section{UV-B treatment}

UV-B irradiation was provided by a single Philips (TL 40W/12, Eindhoven, The Netherlands) ultraviolet-B tube with main output at $312 \mathrm{~nm}$. Culture suspension and immobilized beads were taken in sterile $75 \mathrm{~mm}$ Petri dishes occupying the depth of $0.5 \mathrm{~cm}$ was irradiated under artificial irradiation by UV-B ( $280-315 \mathrm{~nm})$. Samples were exposed for required time period to a PPFD of $20 \mu \mathrm{mol} \mathrm{m}^{-2} \mathrm{~s}^{-1}$ and $0.4 \mathrm{~W} \mathrm{~m}^{-2}$ UV-B. The desired dose of UV-B was obtained by adjusting the distance between UV-B source and cyanobacteria suspension.

\section{Heterocyst frequency}

The frequency of heterocysts was estimated by counting a minimum of 1000 cells using a light microscope (Pettersson et al. 1985). Ammonia production

Ammonia excretion from free-living or immobilized cells of cyanobacteria was measured in cell suspensions shaken continuously at $28 \sim \mathrm{C}$ in air, in a growth medium under photosynthetic photon flux density (PPFD) of $75 \mu \mathrm{molm}^{-2} \mathrm{~s}^{-1}$ and $14 \mathrm{~h}$ photoperiod. Before measurement, the cell suspensions were centrifuged and the ammonium was determined by a colorimetric method Solorzano 1969.

\section{Statistical analysis}

All the data are given as the mean \pm S.E. of three measurements. Statistical analysis was carried out using the SPSS software (SPSS Inc., version 20). The growth, macromolecular content and heterocyst frequency of free cells were compared with Al- acclimatized immobilized cells using paired t-test in order to account for any significant difference, using 0.05 level of significance as the critical value for rejecting the null hypothesis.

\section{RESULTS}

Growth pattern of free living, Al-acclimatized and Al-acclimatized immobilized $\boldsymbol{N}$. muscorum

The free living, Al-acclimatized and Al-acclimatized immobilized $N$. muscorum were

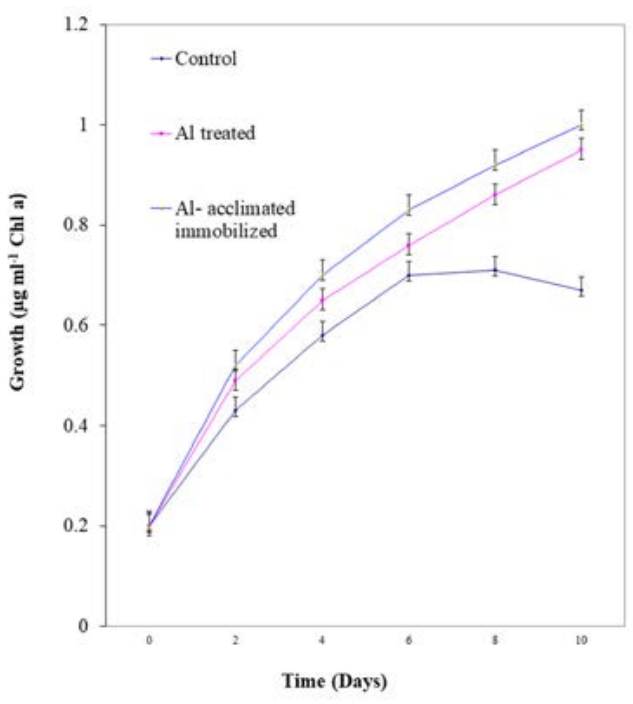

Fig. 1. Growth of free living, Al-acclimatized and Alacclimatized immobilized $N$. muscorumme asured in terms of chlorophyll a at regular intervals upto 10 days. Values are means $\pm S E(n=3)$. 
examined for their growth in terms of content of chlorophyll $a$ at regular intervals for 14 days in liquid medium. Typical sigmoid growth curve was observed in all the cases (Fig. 1). The specific growth rate $\left(\mu_{\max }\right)$ of the same were measured after 14 days of incubation (Table 1). The specific growth rate $\left(\mu_{\max }\right)$ recorded was higher in case of Al acclimatized N. muscorum as compared to free living counterpart demonstrating the high tolerance of the N. muscorum to Al.

Effect of Al- acclimatization and Immobilization on chlorophyll a, MDA and intracellular proline contents of $\boldsymbol{N}$. muscorum

To verify whether Al- acclimatization and immobilization modifies the internal amino acid content, the intracellular proline content of $N$. muscorum was estimated (Table 2). The level of internal proline increased by $21 \%$ in Al-

Table 2. Effect of Al- acclimatization and Immobilization on chlorophyll a, MDA and intracellular proline contents of $N$. muscorum

\begin{tabular}{lcc}
\hline Parameters & Control & $\begin{array}{c}\text { Al- acclimatized } \\
\text { Immobilized }\end{array}$ \\
\hline Chl a & $2.10 \pm 0.02$ & $2.92 \pm 0.04$ \\
Intracellular & $12.50 \pm 0.60$ & $15.13 \pm 1.0$ \\
$\begin{array}{l}\text { Proline } \\
\text { MDA }\end{array}$ & $671 \pm 8$ & $601 \pm 8$ \\
\hline
\end{tabular}

The values represent Means \pm SE $(n=3)$. All the treatments are significantly different $(P<0.01)$

from control (Student's t-test). Units for Chl a $(\mu \mathrm{g} / \mathrm{ml})$; Protein $(\mu \mathrm{g} / \mathrm{ml}) ;$ MDA ( $\mathrm{nmol} / \mathrm{g}$ dry weight); proline ( $\mu \mathrm{g} / \mathrm{g}$ dry weight)

Table 3. Effect of Al-acclimatization and Immobilization on Carotenoid and phycocyanin contents of $N$. muscorum under UV stress

\begin{tabular}{|c|c|c|}
\hline Treatments & Carotenoid & Phycocyanin \\
\hline Control & $0.94 \pm 0.01$ & $14 \pm 0.40$ \\
\hline $\begin{array}{l}\text { Al- acclimatized } \\
\text { Immobilized }\end{array}$ & $0.99 \pm 0.04$ & $14.98 \pm 0.20$ \\
\hline $\begin{array}{l}\text { Control after } \\
\text { UV exposure }\end{array}$ & $0.54 \pm 0.02$ & $7.21 \pm 0.30$ \\
\hline $\begin{array}{l}\text { Al- acclimatized } \\
\text { Immobilized } \\
\text { after UV exposure }\end{array}$ & $0.89 \pm 0.04$ & $13.56 \pm 0.40$ \\
\hline
\end{tabular}

The values represent Means $\pm S E(n=3)$. All the treatments are significantly different $(\mathrm{P}<0.01)$ from control(Student's t-test). Units for Carotenoid $(\mu \mathrm{g} / \mathrm{ml})$; Phycocyanin $(\mu \mathrm{g} / \mathrm{ml})$ acclimatized immobilized as compared to free living $N$. muscorum. These results reasonably indicate the ameliorative role of Al-acclimatization and immobilization on N. muscorum and the same could be attributed to $\mathrm{Al}$ induced dehydration stress which in turn might have accelerated proline production Sharma and Dubey 2005. Moreover, the level MDA was found to be lowered in in Alacclimatized immobilized as compare to free living N. muscorum by $10 \%$.

Effect of Al- acclimatization and Immobilization on cell count of $\boldsymbol{N}$. muscorum

Cyanobacterial filaments were observed with an epifluorescence microscope (ECLIPSE TS100, Nikon) using 20 -fold magnification. It was observed that the cell count showed considerable increment in Al- acclimatized immobilized $\mathrm{N}$. muscorum. Approximately 10000 cells $/ \mathrm{ml}$ were recorded in free living, whereas, the count had been increased to around 16000 cells $/ \mathrm{ml}$. This shows the positive effect of immobilization and Al treatment on cell count. (Fig. 2(b))

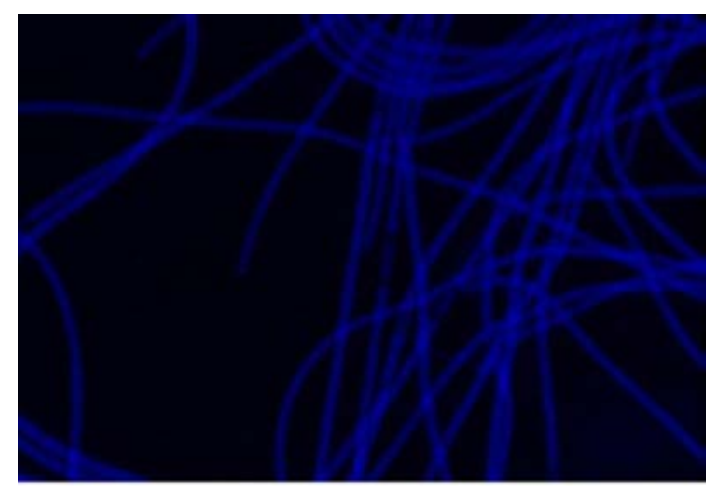

Fig. 2. (a) Nostoc muscorum (20x)

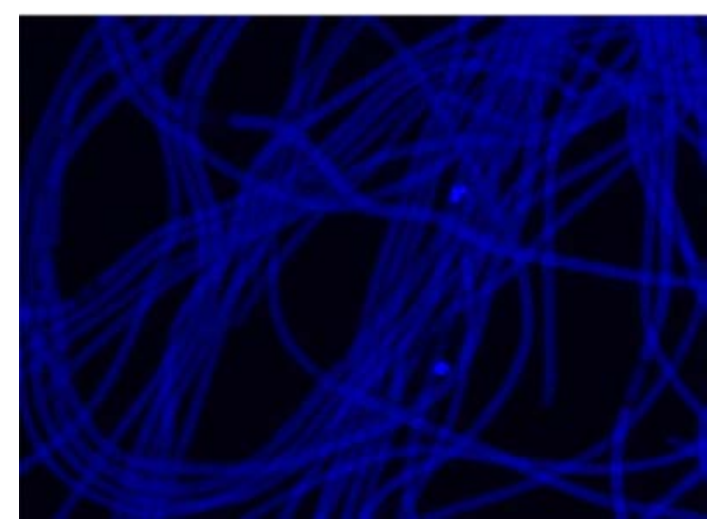

Fig. 2. (b) Al- acclimatized Immobilized Nostoc muscorum (20x) 
Effect of Al-acclimatization and immobilization on carotenoid and phycocyanin contents of $\boldsymbol{N}$. muscorum under UV stress

The aim of microencapsulation is to preserve the viability of encapsulated microbial cells against detrimental environmental factors, such as alterations in $\mathrm{pH}$, damaging metabolic products, osmotic stress and changes in temperature as well as improve storage stability of the microencapsulated cells (Mortazavian et al. 2010). In order to examine the effect of light free living and Al- acclimatized immobilized N. muscorum were exposed to UV stress and the light sensitive cyanobacterial pigments Carotenoid and phycocyanin were evaluated. Contents of carotenoid and phycocyanin were reduced in both free living and Al- acclimatized immobilized $N$. muscorum by UV stress (Table 3 ). However, the decrease in the both carotenoid and phycocyanin content was more pronounced in free living in comparison to Al- acclimatized immobilized $N$. muscorum. The recorded decrease of carotenoid content in free living $N$. muscorum after UV exposure was $42 \%$, however, in case of Al- acclimatized Immobilized $N$. muscorum it was only $10 \%$. Further, same trend was observed in case of phycocyanin content with a reduction of $46 \%$ in free living N. muscorum and merely $9 \%$ of reduction in Al- acclimatized immobilized $N$. muscorum.

Effects of Al- acclimatization and immobilization on the heterocyst frequency of $\boldsymbol{N}$. muscorum

Cyanobacteria or Blue green algae (BGA) are a group of microorganism that can fix the atmospheric nitrogen in their heterocysts. Heterocyst cell has enzyme nitrogenase and is specialised to perform nitrogen fixation (Fay et al. 1992). Free living and Al- acclimatized immobilized

Table 4. Effects of Al- acclimatization and Immobilization on the heterocyst frequency of $N$. muscorum

\begin{tabular}{lcc}
\hline \multirow{2}{*}{ Treatments } & \multicolumn{2}{c}{ Frequency of Heterocyst (\%) } \\
\cline { 2 - 3 } & Day 0 & Day 30 \\
\hline Control & 4.3 & 5.9 \\
Al- acclimatized & 4.6 & 7.8 \\
Immobilized & &
\end{tabular}

The values represent Means $\pm S E(n=3)$. All the treatments are significantly different $(P<0.01)$ from control (Student's t-test).
N. muscorum after incubation for 30 days in BG-11 growth mediawere analyzed under light microscope to examine their heterocyst frequency. It was evident that the heterocyst frequency were increased in both the cases but the increase was more prominent in Al- acclimatized immobilized cultures. (Table 4)

Effect of Al- acclimatization and immobilization on ammonia production in $\mathbf{N}$. muscorum

Free-living and Al- acclimatized immobilized $N$. muscorum were incubated for 30 days in BG-11culture medium under continuous light and with shaking and ammonia accumulation in the culture medium (Table 5) was assayed at various intervals. Ammonia excretion was more under immobilized state than under free-living conditions.

Table 5. Effect of Al- acclimatization and immobilization on ammonia production in $N$. muscorum

\begin{tabular}{lcc}
\hline \multirow{2}{*}{ Treatments } & \multicolumn{2}{c}{ Ammonia production (n moles $/ \mathrm{ml}$ ) } \\
\cline { 2 - 3 } & Day 0 & Day 30 \\
\hline Control & $342 \pm 0.02$ & $725 \pm 0.04$ \\
$\begin{array}{l}\text { Al- acclimatized } \\
\text { Immobilized }\end{array}$ & $365 \pm 0.01$ & $1120 \pm 0.02$ \\
\end{tabular}

The values represent Means $\pm S E(n=3)$. All the treatments are significantly different $(P<0.01)$ from control(Student's t-test). Units for ammonia ( $\mathrm{n}$ moles/ml).

\section{Regeneration Study of Nostoc muscorum from Desiccated Calcium Alginate Beads}

When air-dried at room temperature for 2-3 days, the calcium alginate beads along with the immobilized cyanobacteria shrunk to the size of mustard seeds. When transferred into nutrient medium, the beads swelled up almost to their original size. The filaments of $N$. muscorum were visible in the liquid medium after 8 days. These were then used to inoculate fresh BG-11 medium and their growth and heterocyst frequency were measured. These parameters were found to be comparable to the free-living $N$. muscorum. The same process of transferring air-dried beads to fresh media was repeated every 15-16 days to evaluate the viability of these desiccated cyanobacteria cells. The cells in these air-dried beads were found to be highly strong and produced viable colonies upto several months. This yet again has profound implications in potential application 
of $\mathrm{N}_{2}$-fixing cyanobacteria in nitrogen poor soils. It is clear from the experiments performed that calcium alginate does not have any unfavourable effects on the regeneration potential and $\mathrm{N}_{2}-$ fixing capability of N. muscorum. (Table 6).

Table 6. Effects of Al- acclimatization and Immobilization on chlorophyll a content and heterocyst frequency in free living and Al acclimatized immobilized $N$. muscorumafter 8 days of resuspensionin BG-11 growth medium.

\begin{tabular}{lcc}
\hline Parameters & Control & $\begin{array}{c}\text { Al- acclimatized } \\
\text { Immobilized }\end{array}$ \\
\hline Chl a & $3.10 \pm 0.02$ & $3.92 \pm 0.04$ \\
Heterocyst & $4.3 \pm 0.03$ & $4.6 \pm 0.02$ \\
frequency & & \\
\hline
\end{tabular}

The values represent Means $\pm S E(n=3)$. All the treatments are significantly different $(P<0.01)$ from control(Student's $\mathrm{t}$-test). Units for $\mathrm{Chl} \mathrm{a}(\mu \mathrm{g} / \mathrm{ml})$

Table 7. Effect of inoculation of Al- acclimatized immobilized N. muscorum on the root, shoot and biomass of rice seedlings in pots (variety Saryu 52)

\begin{tabular}{|c|c|c|c|c|c|c|}
\hline \multirow[t]{2}{*}{ Treatments } & \multicolumn{2}{|c|}{$\begin{array}{c}\text { Shoot } \\
\text { length }(\mathrm{cm})\end{array}$} & \multicolumn{2}{|c|}{$\begin{array}{l}\text { Root } \\
\text { length }(\mathrm{cm})\end{array}$} & \multicolumn{2}{|c|}{$\begin{array}{c}\text { Biomass (mg fresh } \\
\text { wt./seedling) }\end{array}$} \\
\hline & Day 15 & Day 30 & Day 15 & Day 30 & Day 15 & Day 30 \\
\hline Control & 4.2 & 10.8 & 2.8 & 3.4 & 54.1 & 70.3 \\
\hline N. muscorum & 5.4 & 13.3 & 3.2 & 3.9 & 59.6 & 74.8 \\
\hline $\begin{array}{l}\text { Immobilized } \\
\text { N. muscorum }\end{array}$ & 6.1 & 14.7 & 3.8 & 4.2 & 62.1 & 77.3 \\
\hline $\begin{array}{l}\text { Al- accli Imm } \\
\text { N. muscorum }\end{array}$ & 6.9 & 16.5 & 4.4 & 5.3 & 76.2 & 131.6 \\
\hline $\mathrm{NaCl}$ & 3.9 & 5.1 & 1.9 & 2.2 & 36.7 & 38.0 \\
\hline $\begin{array}{l}\mathrm{NaCl}+\mathrm{Al} \text { - accli } \\
\mathrm{Imm} N \text {. muscorum }\end{array}$ & 4.9 & 11.3 & 2.6 & 3.1 & 44.5 & 52.5 \\
\hline $\mathrm{CdCl}_{2}$ & 3.3 & 4.3 & 1.3 & 1.6 & 30.2 & 33.3 \\
\hline $\begin{array}{l}\mathrm{CdCl}_{2}+\mathrm{Al} \text { - accli } \\
\mathrm{Imm} N \text {. muscorum }\end{array}$ & 4.0 & 10.5 & 2.1 & 2.9 & 37.1 & 43.7 \\
\hline
\end{tabular}

The values represent Means $\pm S E(n=3)$. All the treatments are significantly different $(P<0.01)$ from control(Student's t-test).

\section{DISCUSSION}

The specific growth rate $\left(\mu_{\max }\right)$ recorded was higher in case of Al acclimatized $N$. muscorum as compared to free living counterpart demonstrating the high tolerance of the $N$. muscorum to Al. This finding is in consonance with the reports of Hussaini et al., 1996 which showed that low concentration of $\mathrm{Al}$ in the form of $\mathrm{AlCl}_{3}$ were noninhibitory to N.linckia at pH 7.5 and establishes the fact that low concentrations can sometimes

\section{Ability of Al- acclimatized immobilized Nostoc muscorum to combat abiotic stress and its potential as a Biofertilizer}

In the present experiments the ability of Al- acclimatized immobilized $N$. muscorum was examined in order to combat abiotic stress and to explore its potential as a Biofertilizer. The inoculation of Al- acclimatized immobilized N.muscorum in pots increased the growth of the rice seedlings. Moreover, it was observed that ammonia excretion was more under immobilized state than under free-living conditions which could have positive effect on the growth of rice seedlings. Further, we have noticed a unique pattern of results with $\mathrm{Al}$ exposure in N.muscorum showing less toxicity or protection towards salt $(\mathrm{NaCl})$ and heavy metal stress $\left(\mathrm{CdCl}_{2}\right)$ which actually have resulted relatively more damaging effects on rice plants. (Table 7) effects as was suggested by Foy, 1983. It was evident that growth was further enhanced in the Al-acclimatized immobilized $N$. muscorum. Similar result was indicated by Uma and Kannaiyan, 1996 where the colonization and immobilization of cyanobacterial cells in the PU foam resulted in increased growth. Immobilization-induced additional enhancement in growth of $N$. muscorum may be due to the mechanical support provided 
by the matrices Mahesh and Kannaiyan 1996. The study conducted by Chris et al. 2006 provided similar evidence as was evident from the present study, on ameliorative role of exogenous proline in detoxification of harmful ROS generated under UV stress. Such a possibility is not ruled out in the cyanobacterium under metal stress and thereby the level of MDA content was found to be reduced due to Al-induced over production of proline in Al acclimatized immobilized $N$. muscorum. Further, the level of chla and protein increased by $39 \%$ and $24 \%$ in Al-acclimatized immobilized as compared to free living $N$. muscorum respectively (Table 2 ). A similar finding was also reported by Brouers et al.1988 in which it was evident that growth was enhanced in algal cells in the foam immobilized state.

The result related to cell count finds support from the findings of Kannaiyan et al. 1997 who examined the colonization and immobilization of cyanobacterial cells in the PU foam by light microscopy. Initial colonization of the foam surface by the cyanobacteria was followed by penetration into the foam pores where intact cells with heterocysts were observed and it was marked that growth was enhanced in the foam immobilized state.

It was evident that both carotenoid and phycocyanin content were enhanced in Al- acclimatized Immobilized $N$. muscorum indicating the role of Carotenoid and phycocyanin in cyanobacteria as a general defense against photooxidation under stress (Quesada 1995). The result also shows the protective role of Alacclimatization and immobilization on exposure to UV stress in N. muscorum.

Increase in heterocyst frequency is in accordance with results obtained in study conducted by Pettersson et al., 1985 using the cyanobacterium Anabaena cylindrical as test organism where the frequency of heterocysts increased at all concentrations of Al after 120 h of treatment. Furthermore, Syiem in 2005 showed that the immobilized cells of Nostoc ANTH exhibited increased heterocyst frequency in $\mathrm{N}_{2}$ - grown cultures as compared to $\mathrm{N}_{2}$ - grown free- living cultures under identical conditions. It is clear from the above-mentioned discussion that cyanobacterial isolates have a higher frequency of heterocysts under the immobilized state than their free-living counterparts. This action could be attributable to a mechanical diffusion barrier provided by the alginate matrix up to a definite extent limiting the fast access of oxygen to the cells existing in the core of the beads, thus allowing heterocyst cells to grow and multiply normally for a longer period of time.

Ammonia excretion was more under immobilized state than under free-living conditions. This might be due to the higher heterocyst frequency observed under immobilized state. Similar ruling with increased ammonia production in immobilized cyanobacteria were reported earlier which support our findings (Mahesh and Kannaiyan 1993; Brouers and Hall 1986)

The use of calcium alginate in making cyanobacterial beads may be argued as it is not cost effective, but easy handling, long storage life and high percentage of regeneration capabilities outweigh the initial cost in long run (Syiem 2005)

It was observed that ammonia excretion was more under immobilized state than under free-living conditions which could have positive effect on the growth of rice seedlings. Similarly, Samal and Kannaiyan 1992 had earlier noted ammonia excretion by $A$. azollae immobilized in alginate and its positive effect on the growth of rice seedlings. Latorre et al., 1986 demonstrated that the growth of rice plants in the laboratory was improved by the inoculation of $A$. variabilis SAO (wild type) and SA1 (mutant) strains. This enhancement in the growth of the rice plant due to inoculation was suggested to be the consequence of ammonia production by the cyanobacteria. The favorable effects of inoculation of immobilized cyanobacteria in rice seedlings could be partly attributable to growth promoting substances in addition to a nitrogen input by the cyanobacteria. The effect of heavy metal (Cd) and salinity stress was lowered in plants treated with Al acclimated and immobilized N.muscorum. This could be due to the fact that proline may confer a positive role in the protection of N.muscorum under Al stress along with the induction of various dehydrin-like proteins commonly known to get induced in higher plants under drought or dehydration stress (Sharma and Dubey, 2005). 
Thus the present study will give a new dimension to the existing biofertilizer and provide a more stress tolerant biofertilizer with improved storage capability and portability to enhance the crop productivity.

\section{ACKNOWLEDGMENTS}

We are grateful to the Vice Chancellor, Integral University, Lucknow, India, for providing financial assistance and necessary laboratory facilities. The manuscript has been approved by competent authority of University and the assigned communication number is IU/R\&D/2019MCN000689.

\section{CONFLICT OF INTEREST}

The authors declares that there is no conflict of interest.

\section{FUNDING}

None.

\section{AUTHORS' CONTRIBUTIONS}

All authors listed have made a substantial, direct and intellectual contribution to the work, and approved it for publication.

\section{DATA AVAILABILITY}

All datasets generated or analyzed during this study are included in the manuscript and/or the Supplementary Files.

\section{ETHICS STATEMENT}

This article does not contain any studies with human participants or animals performed by any of the authors.

\section{REFERENCES}

1. Barcelo J, Poschenrieder C. Review Fast root growth responses, root exudates, and internal detoxification as clues to the mechanisms of aluminium toxicity and resistance: a review. Environ Exp Bot. 2002;48:75-92. https://doi.org/10.1016/S0098-8472(02)00013-8

2. Bhardwaj D, Ansari WM, Sahoo KR, Tuteja N. Biofertilizers function as key player in sustainable agriculture by improving soil fertility, plant tolerance and crop productivity. Microb cell Fact. 2014;13(66):45. https://doi.org/10.1186/1475-2859-13-66

3. Brahmaprakash GP, Sahu PK. Biofertilizers for Sustainability. J Indian Inst Sci. 2012;92:37-62.

4. Brouers M, Hall DO. Ammonia and hydrogen production by immobilized cyanobacteria. J Biotechnol. 1986;3:307-321. https://doi.org/10.1016/0168-
1656(86)90012-X

5. Brouers M, Shi DJ, Hall DO. Immobilization Methods for Cyanobacteria in Solid Matrices. Methods Enzymol. 1988;16:629-636. https://doi.org/10.1016/00766879(88)67073-X

6. Choudhary M, Jetley KU, Khan MA, Zutshi S, Fatma T. Effect of heavy metal stress on proline, malondialdehyde, and superoxide dismutase activity in the cyanobacterium Spirulina platensis-S5. Ecotoxicol Environ Saf. 2007;66:204-209. https://doi. org/10.1016/j.ecoenv.2006.02.002

7. Chris A, Zeeshan M, Abrahama G, Prasad SM. Proline accumulation in Cylindrospermum sp. Environ Exp Bot. 2006;57:154-159. https://doi.org/10.1016/j. envexpbot.2005.05.008

8. Fay P. Oxygen Relations of Nitrogen Fixation in Cyanobacteria. Microbiol Rev. 1992;56:340-373. https://doi.org/10.1128/MMBR.56.2.340-373.1992

9. Fodor E, Nagy AS, Erdei L. The Effects of Cadmium on the Fluidity and H+ -ATPase Activity of Plasma Membrane from Sunflower and Wheat Roots. J Plant Physiol. 1995;147:87-92. https://doi.org/10.1016/ S0176-1617(11)81418-5

10. Foy CD. The physiology of plant adaptation to metal stress. lowa State J Res. 1983;57:355-391.

11. Foyer CH, Noctor G. Redox Regulation in Photosynthetic Organisms: Signaling, Acclimation, and Practical Implications. Antioxidants \& Redox Signaling. 2009;11:4. https://doi.org/10.1089/ars.2008.2177

12. Gendel SM, Nohr RS. Growth and nitrogen fixation by immobilized cyanobacteria. App/ Microbiol Biotechnol. 1989; 31:138-145. https://doi.org/10.1007/ BF00262451

13. Heath RL, Packer L. Photoperoxidation in isolated chloroplast: I. Kinetics and Stoichiometry of fatty acid peroxidation. Arch Biochem Bioph. 1968;125:189-98. https://doi.org/10.1016/0003-9861(68)90654-1

14. Herbert D, Phipps PJ, Strange RE. Chemical analysis of microbial cells. Methods Microbiol. 1971;3. https:// doi.org/10.1016/S0580-9517(08)70641-X

15. Horst WJ. The role of the apoplast in aluminum toxicity and resistance of higher plants: a review. $Z$ Pflanzenernahr Bodenk. 1995;158:419-428. https:// doi.org/10.1002/jpln.19951580503

16. Huges EO, Garham PR, Zehrider A. Toxicity of a unialgal culture of Microcystisaeruginosa. Canadian J Microbiol. 1958;4:215-236. https://doi.org/10.1139/ m58-024

17. Husaini Y, Rai LC, Mallick N. Impact of aluminium, fluoride and fluoroaluminate complex on ATPase activity of Nostoc linckia and Chlorella vulgaris. BioMetals. 1996;9:277-283. https://doi.org/10.1007/ BF00817928

18. Kannaiyan S, Aruna SJ, Merina S, Hall DO. Immobilized cyanobacteria as a biofertilizer for rice crops. J App Phycology. 1997;9:167-174. https://doi. org/10.1023/A:1007962025662

19. Kozlowski TT, Pallardy SG. Acclimation and adaptive responses of woody plants to environmental stresses. Bot Rev. 2002;68:270-334. https://doi. org/10.1663/0006-8101(2002)068[0270:AAAROW]2 $.0 . \mathrm{CO} ; 2$ 
20. Latorre JH, Lee H, Spiller, Shanmugam KT. Ammonium ion - excreting cyanobacterial mutant as a source of nitrogen for growth of rice: a feasibility study co. Biotechnol Lett. 1986;8(7):507-512. https://doi. org/10.1007/BF01025211

21. Lei YB, Yin CY, Li CY. Differences in some morphological, physiological, and biochemical responses to drought stress in two contrasting populations of Populusprzewalskii. Physiol Plant. 2006;127:182-91. https://doi.org/10.1111/j.1399-3054.2006.00638.x

22. Lowry OH, Rosenbrough NJ, Farr AL, Randall RJ. Protein measurement with the folin phenol reagent. I Biol Chem. 1951;193:269-75.

23. Ma JF, Ryan PR, Delhaize E. Aluminium tolerance in plants and the complexing role of organic acids. Trends Plant Sci. 2001;6(6):273-278. https://doi.org/10.1016/ S1360-1385(01)01961-6

24. Mahesh G, Kannaiyan S. Effect of immobilization of cyanobacteria in solid matrix on ammonia excretion and nitrogen fixing activity. Biotech Lett. 1993;15:975978. https://doi.org/10.1007/BF00131767

25. Mortazavian A, Razavi SH, Ehsani MR, Sohrabvandi $\mathrm{S}$. Principles and methods of microencapsulation of probiotic microorganisms. Iran J Biotechnol. 2010;5:2007-2020.

26. Myers J, Kratz WA. Relationship between pigment content and photosynthetic characteristics in a blue green alga. J Gen Physiol. 1995;39:11-21. https://doi. org/10.1085/jgp.39.1.11

27. Pettersson A, Hallbom L, Bergman B. Physiological and structural responses of the cyanobacterium Anabaena cylindrica to aluminium. Phvsiol Plant. 1985;63:153158. https://doi.org/10.1111/j.1399-3054.1985. tb01895.x

28. Pinkerton A, Simpson RJ. Interactions of surface drying and subsurface nutrients affecting plant growth on acidic soil profiles from an old pasture. Aust J Exp Agric. 1986;26:681-9. https://doi.org/10.1071/EA9860681

29. Quesada A. Growth of antarctic cyanobacteria under ultraviolet radiation: UVA counteracts UVB inhibition.
J Phpl. 1995;31:242-248. https://doi.org/10.1111/ j.0022-3646.1995.00242.x

30. Rai LC, Singh AK, Mallick N. Studies on photosynthesis, the associated electron transport system and some physiological variables of Chlorella vulgaris under heavy metals stress. J Plant Physiol. 1991;137:419-24. https://doi.org/10.1016/S0176-1617(11)80310-X

31. Rengel Z. Uptake of aluminiuin by plant cells. New Phytol. 1996;134:389-406. https://doi. org/10.1111/j.1469-8137.1996.tb04356.x

32. Samal KC, Kannaiyan S. Isolation of the algal symbiont Anabaena azollae and the role of vitamins in growh, heterocyst development and nitrogen fixing activity. Folia. Microbial. 1992;37(6):421-426. https://doi. org/10.1007/BF02899900

33. Sharma P, Dubey SR. Modulation of nitrate reductase activity in rice seedlings under aluminium toxicity and water stress: role of osmolytes as enzyme protectant. J Plant Physiol. 2005;162:854-864. h t t p s : / / d o i . org/10.1016/j.jplph.2004.09.011

34. Syiem MB, Bhattacharjee A. An efficient protocol for long-term preservation of cyanobacteria. J Adv Lab Res Biol. 2010;1:53-59.

35. Syiem MB. Entrapped Cyanobacteria: Implications for biotechnology. Indian J Biotechnology. 2005;4:209215.

36. Uma D, Kannaiyan S. Effect of the systemic fungicide, Bavistin on the nitrogen status of cyanobacteria under immobilized state in polyurethane foam. $S$ Afr J Bot. 1996;62(3):127-132. https://doi.org/10.1016/S02546299(15)30611-6.

37. Yin C, Penga Y, Zang R, Zhua Y, Lia C. Adaptive responses of Populuskang dingensis to drought stress. Physiol Plant. 2005;123:445-451. https://doi.org/10.1111/ j.1399-3054.2005.00477.x

38. Zhang JZ, Creelman RA, Zhu JK. From laboratory to field: Using information from Arabidopsis to engineer salt, cold, and drought tolerance in crops. Plant Physiol. 2004;135:615-621. https://doi.org/10.1104/ pp.104.040295 